\title{
Agile Project Management: Brief Review
}

\author{
Haifa Mohammed and Abdul Rauf
}

\begin{abstract}
In this paper we review the importance of agile in project management and the differences between it and traditional methods where agile method is an alternative traditional method and features that made the agile superior to traditional methods. We will mention the most important factors of operations of agile software development. We also describe in this paper the most common challenges of agile faced by team and benefits that accrue to the project when using agile method. This paper focus different methodologies used agile and most popular and the most common used like Scrum, Feature Driven development, Extreme Programing and stage each method and most benefits each method. This paper includes comparison between Scrum and Extreme programing. Finally we review the most drawbacks of agile management.
\end{abstract}

Index Terms-Management agile, scrum, XP, feature driven development.

\section{INTRODUCTION}

Agile is new approach to software development adopted by some companies in their projects in recent years such as Yahoo and Google. Agile is method to software development depend on iterative and incremental development by self-organization and different team software is developed.

Agile approach successfully outperformed the traditional approach [1] that called waterfall model see Fig. 1, which was focused in the first phase to determine the requirements that must be provided is complete and accurate, and this leads to some problems due to the inability of the client to provide all the information is detailed and accurate.

Also when determining the time at which it is put and completeness requirements and the time the project ends will be a long time and this leads to the failure of the project due to changes in business processes or change the requirements of a client who wants to project. These are some drawbacks in the traditional approach, only interested in identifying requirements and secure the scope and the project manager will be forced to determine the time and budget. It is not easy to change in the system after a period of time, because of the long time when developing requirements and delivery system. The client will be unable to see the tasks completed.

Most companies did rely on agile development due to its importance in helping to manage software projects and help to move quickly to offer new programs. Agile developed by a Toyota [2] in the last decades of the twentieth century production system well termed the beginning of the name of the system Toyota productive, that was quickly developed

Manuscript received April 28, 2014; revised July 31, 2014.

The authors are with College of Computer and Information Sciences, Al-Imam Mohammad Ibn Saud Islamic University (IMSIU), Riyadh, Saudi Arabia (e-mail: almotairyhaifa@gmail.com, rauf.malik@ccis.imamu.edu.sa). later to become the new concept, a manufacturing agile, that the manufacturing agile has been used by many of the industrial companies in order to reduce or the elimination of all forms of waste, since his philosophy is based on reducing its initial materials in order to obtain the same output as well as the elimination of al forms of waste. Agile is cycle iterative contain a set of software development methodologies. Key factors in the agile software development are customer and self-organization. Customers assist the client in making the decision and determine the direction of the project and the setting of priorities and features. Determined feature by client through the client describe the behavior of the system without enter into the details of implementation and verification of these features as satisfy the client. The feature done when feature pass of all system stage and pass in accept test. Agile interested in the work of the changes in the project and care about the benefits of the work presented to the customer and supports source code for its longer duration. Agile focus on the delivery of code and ignore documents and analysis and design, which leads to a lack of documentation in the company. It is possible in this technical change requirements and the development environment.

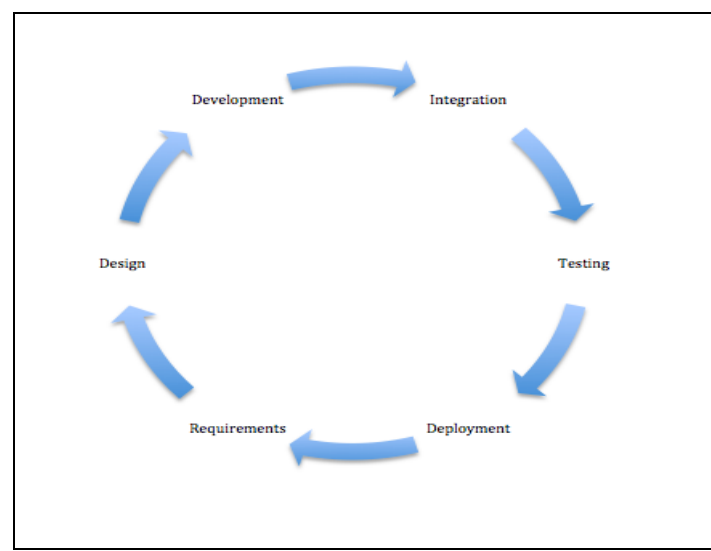

Fig. 1. Traditional approach.

TABLE I: DIFFERENCE BETWEEN TRADTIONAL AND AGILE

\begin{tabular}{|l|l|}
\hline Traditional & Agile \\
\hline $\begin{array}{l}\text { Depend on tools and } \\
\text { process. }\end{array}$ & $\begin{array}{l}\text { Depends on the cooperation of the } \\
\text { team and the people. }\end{array}$ \\
\hline $\begin{array}{l}\text { Work documents measuring } \\
\text { each activity. }\end{array}$ & $\begin{array}{l}\text { Software is used to measure the } \\
\text { progress of the project and more } \\
\text { interested in the design code. }\end{array}$ \\
\hline $\begin{array}{l}\text { The client is not constantly } \\
\text { participation. }\end{array}$ & Participation the client constantly. \\
\hline $\begin{array}{l}\text { Not allowed to change } \\
\text { during the project. }\end{array}$ & $\begin{array}{l}\text { Allowed to change during the } \\
\text { project. }\end{array}$ \\
\hline $\begin{array}{l}\text { Does not permit the } \\
\text { extradition continuously } \\
\text { working for the client. }\end{array}$ & $\begin{array}{l}\text { Permit the extradition continuously } \\
\text { working for the client. }\end{array}$ \\
\hline
\end{tabular}

The table below illustrates some of the fundamental differences between traditional software and agile 
approaches for project management see Table I [2]-[5].

\section{AgILE BenIFITES}

There are many advantages when use agile on project [1]-[3], [6]:

- Help manger ability to understand the plan of the organization

- See how much progress has been made and what they do if they encountered problem during this plan.

- Managers executives can get on the developments of the project's progress for make the decision.

- Less any surprise in project and expectations of the results at the end of the project and put the plan in the event of adding changes in project.

- Risk management and ability to change the requirement of program.

- Supports the work of the source code for the longest period.

- The project manager will be aware of the time and budget and the tasks that have been completed.

- It is low cost.

\section{Challenges OF Agile}

Agile team faces many of challenges [7] these challenges are the most common [8]:

- Changes the environment that occurs at wrong time.

- Changes requirement and incomplete.

- Not knowing what the customer wants by making communication with stakeholder in every phase.

- Keep pace with the evolution of technology and progress quickly.

\section{Methods}

In this section we will provide different methods [9] that focus some agile methods to manage projects practices (Scrum, FDD) and others on the implementation of programs practices (XP). We will review the most popular methods and most commonly used and benefits each method.

\section{A. Extreme Programing (XP)}

Established Extreme Programing based on the problems that have emerged in the traditional development. XP life cycle is divided into three phases Fig. 2, namely:

Exploration: Describe the features desired by the customer in the program. At this stage, also puts the team works tools and techniques that will be used in the program. Then built initial model, it takes several weeks.

Planning: order of priority tasks, which will be performed and the development of the project schedule. Put the plan takes some days.

Iteration release: Divided scheduling established in the planning stage to the number of iterations. In each iteration features tested by the client. Upon completion of all iterations become the system is ready for production.

Productionizing: At this stage is a test system and test performance before handing it to the customer.
Maintain: Maintaining the system during run production of the system and also is producing new iterations may require put new people in the team.

Death: Death occurs if the system did not provide the expected results or if the cost of development expensive.



The aim of Extreme Programming, the software development is successful, even if there is a change in the ongoing requirements. Participation of the client in the project. Characterized in that short iterations and small release in every month and also the communication and coordination and integration among the members of the project.

\section{B. Scrum}

In this method, the focus is on the work of the team members in a changing environment for the production system. This method consists of three stages Fig. 3, namely:

Pregame: This phase consists of two parts planning and architecture. Planning Contains a system that will be developed. Creates product backlog that knows what is required in the final product and contains all the requirements that create from the requirements of the customer, sales, marketing or software developers. Estimated effort and prioritize tasks. Defines the project team and tool and risk assessment tools and update product backlog. Architecture contains a high level of system and includes structure based on the items in the product backlog.

Development: it is agile part in scrum method. Treated, as a black box cannot be predicted. Controls the different environments and different techniques such as time, resources and technology that change through the project even be able to adapt flexibly to changes. Sprint develops that contain repeated cycles intended for the development and improvement of new production increases. In all Sprints contain requirements analysis, design, development and delivery.

Postgame: Implement this phase when requirements are complete. Preparing for the release of the system and contain this stage on the functions of integration and testing and documentation.

This system has been implemented on the car manufacturers in sales in order to improve efficiency and allows users to see the results at the earliest. These methods resulted in decrease errors greatly and increase the efficiency of teamwork and team harmony and interdependence and ensure the quality and delivery of the project early on. 


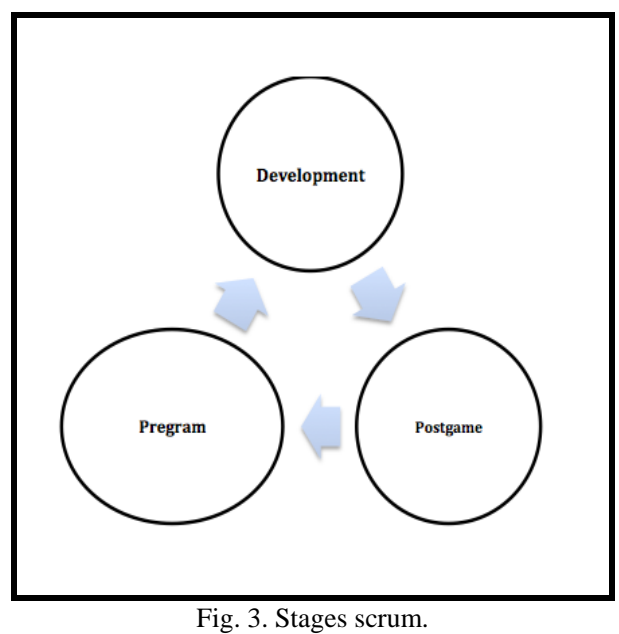

These some benefits scrum in project helps to increment production and considered a simple operation for complicated projects. Updated automatically to changing requirements and add fresh requirements and delivers the tasks that have been completed. The project manager can see whether the priorities of the project have been completed and delivered. Director also compares the price and the time estimated to complete the project with the date and the budget specific for the project ends.

Comparison between scrum and XP, the scrum their rules were simple and easy to use and contain powerful advantages.

The table below illustrates the simple differences between scrum and XP see Table II.

TABLE II: DIFFRENCE BETWEEN SCRUM AND XP

\begin{tabular}{|c|l|l|}
\hline \multirow{2}{*}{ Iteration } & $\begin{array}{l}\text { Scrum } \\
\text { The iterations called } \\
\text { "Sprint" take time } \\
\text { from two weeks to a } \\
\text { month. }\end{array}$ & $\begin{array}{c}\text { Take the time } \\
\text { duration of a week or } \\
\text { two. }\end{array}$ \\
\hline Change & $\begin{array}{l}\text { Not allowed to } \\
\text { change during the } \\
\text { sprint. Offers product } \\
\text { backlog elements are } \\
\text { not changed during } \\
\text { the sprint. }\end{array}$ & $\begin{array}{l}\text { Able to change during } \\
\text { the iteration if you do } \\
\text { not start working a } \\
\text { certain feature. Can } \\
\text { switch on iteration if do } \\
\text { not start working on the } \\
\text { feature. }\end{array}$ \\
\hline Priority & $\begin{array}{l}\text { Owner product puts a } \\
\text { priority of product } \\
\text { backlog. The team } \\
\text { chooses the sequence of } \\
\text { the items that will be } \\
\text { worked. It may be the } \\
\text { highest priority can not } \\
\text { do it in the Sprint was } \\
\text { replaced by another } \\
\text { priority. }\end{array}$ & $\begin{array}{l}\text { Order of priority based } \\
\text { on the client's request. } \\
\text { Execute by the team on } \\
\text { the basis of this } \\
\text { arrangement. }\end{array}$ \\
\hline Project members \\
$\begin{array}{l}\text { Working with a small } \\
\text { team size and average } \\
\text { size and the maximum } \\
\text { 20, a member of the } \\
\text { project. }\end{array}$ & $\begin{array}{l}\text { Method is suitable for } \\
\text { small team less than 10 } \\
\text { members in the project. }\end{array}$ \\
\hline
\end{tabular}

\section{Feature Driven Development (FDD)}

It is a way to develop the system, and this method is not developing software full but only focus on the design and construction phases. Designed to work with other activities for the development of software and does not require a specific format for the user process model. Focuses on quality at all stages of the process and control and monitor progress made in the project. FDD consists of five stages Fig. 4 where the design and construction systems.

Develop an overall model: At this stage, be aware of the scope and system requirements for the building. Domain experts offer walk through which is a high-level description of the system to the team and chief engineer. The overall domain divide domain to many different domain that contain more details to walk through which works by members of the domain. After each walk through each development team working in small groups to produce object model to domain area.

Build a feature list: By the presence of walk through and object model and documentation requirements will give a comprehensive list of system and distinctive. The development team provides to client's functional value included in the system. Exposure functions for each area and the areas of functional groups composed of a set of basic features. The primary feature is divided into a set of features and represents a particular area in various activities. The client and sponsor are working on review a list of the features of the system to make sure it is correct and complete.

Plan by feature: At this stage the plan is the establishment of a high level and develop a set of features in a sequence based on their priority and is appointed chief programmers. Scheduling and determent key features.

Design by feature and build by feature: A set of features has been selected a small group of them and are developed by a team feature is considered as an iterative process through which the production of specific features. Takes a couple of days per iteration and maximize couple of weeks. Possible the work of more than one team for the feature works in concurrence to design and build a range of features. There are existing tasks in each iteration, a design inspection and code and test and integration and code inspection. After the completion of the feature and success of the iteration promote to the main building and then takes a set of features taken from the feature set.

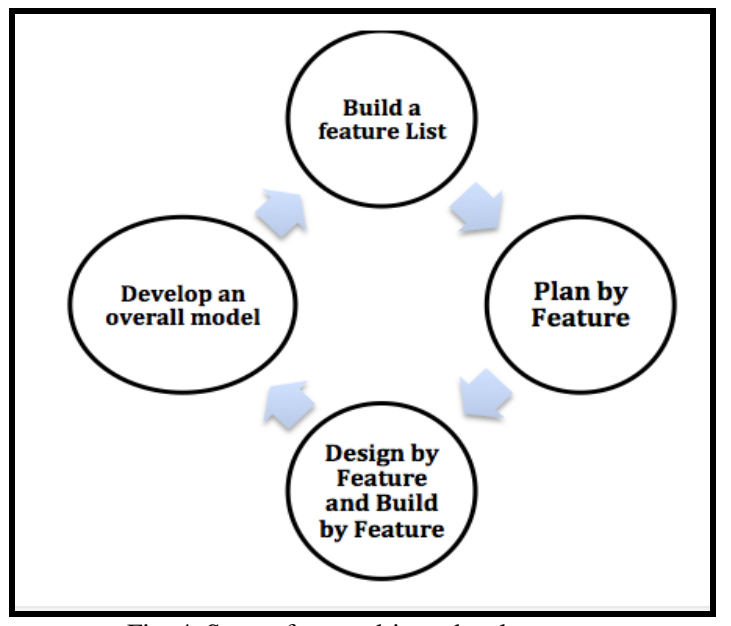

Fig. 4. Stages feature driven development

\section{DRAWBACK OF AgILE MANGMENT}

Despite the many benefits that we get from the use of agile there are disadvantage in this method. Do not use agile processes in large enterprises because they do not include 
documents. Difficult to put the budget and effort at the beginning of the project because it initially did not specify details of the project scope. Used by developers with high efficiency and great experience and novice programmers cannot work with it, but work with experienced. You need many meetings with stakeholders. Continuation of the development of the project area because of the lack of limits on the scope of the project.

\section{CONCLUSION}

This paper made review methods processes agile and challenges faced and benefits of agile development that makes them better than traditional methods. The goal of this research is to know more about the approach of agile software development and clarify the difference from the traditional approach. The traditional approach, which cannot change during the project work projects while agile able to change and able risk management, budget and scope and to create valuable products and be successful.

\section{REFERENCES}

[1] M. Karlesky and M. Vander, "Agile project management (or, Burning Your Gantt Charts),” in Proc. Embedded Systems Conference Boston (Boston, Massachusetts), October 2008, pp. 247-267.

[2] R. Morien, "Agile management and the Toyota way for software project management," in Proc. 3rd IEEE International Conference on Industrial Informatics (INDIN), Aug. 2005, pp. 516-522.

[3] G. B. Alleman, "Agile project management methods for it projects," in The Story of Managing Projects: A Global, Cross-Disciplinary
Collection of Perspectives, E. G. Carayannis and Y. H. Kwak ed., 2002, p. 324.

[4] A. Aitken and V. Ilango, "A comparative analysis of traditional software engineering and agile software development," in Proc. 46th Hawaii International Conference on System Sciences, 2013, vol. 108, pp. 4751-4760.

[5] P. Soldán and L. Landryová, "Agile methods of project management," in Proc. the 2011 12th International Carpathian Control Conference (ICCC), May 2011, p.30.

[6] Y. Yang, "Enterprise project portfolio management and agile software development: Combining creativity and governance," August 2011.

[7] H. Hajjdiab and A. S. Taleb, "Adopting agile software development: Issues and challenges," International Journal of Managing Value and Supply Chains (IJMVSC), vol. 2, no. 3, September 2011.

[8] P. G. Smith and J. Oltmann, "Flexible project management: Extending agile techniques beyond software projects," PMI Global Congress--North America (2010: Washington, D.C.), 2010, vol. 9, pp. 20-25.

[9] P. Abrahamsson, O. Salo, J. Ronkainen, and J. Warsta, Agile Software Development Methods Review and Analysis, VTT Publication, pp. 478-107, 2002.

Haifa Mohammad has completed her MS degree from College of Computer and Information Sciences, Al-Imam Mohammad Ibn Saud Islamic University (IMSIU), Riyadh, Saudi Arabia. She is interested in doing researches in the fields of software engineering and search based software testing in future.

Abdul Rauf received his B.Sc. degree from Punjab University Lahore, Pakistan in 2004. Then he earned his M.S. \& Ph.D degrees in computer science from National University of Computer and Emerging Sciences, NUCES-FAST, Islamabad, Pakistan. Currently he is working as an assistant professor at College of Computer and Information Sciences, Al-Imam Muhammad ibn Saud Islamic University, Riyadh, Saudi Arabia. His research interests include software testing, software quality assurance, software project management, software process improvement and software requirement engineering. 